\title{
ASSESSING THE COMPETITIVENESS OF EDUCATIONAL PROGRAMS FOR THE GLOBAL ENERGY SECTOR
}

\author{
LAZAR GITELMAN, MICHAEL KOZHEVNIKOV \& GALINA CHEBOTAREVA \\ Academic Department of Energy and Industrial Management Systems, Ural Federal University, Russia
}

\begin{abstract}
The article outlines the results of the authors' research into approaches to the implementation of educational products for the global energy sector that meet industry-specific challenges of today. The authors identify the distinguishing features of global energy education that determine the need for its synchronization with the development of the world's energy markets. The authors summarize the experience of designing such educational programs by leading universities of the world. The summary makes it possible to identify a number of benchmarks for comparative analysis of the content characteristics of the programs (inclusion of interdisciplinary courses, territorial and modular flexibility, network cooperation etc.). The authors have designed their own method of assessing the competitiveness of educational programs for the global energy sector that is based on the above indicators and includes building a registry of universities that participate in the market of global energy education. The method also provides for comparison and expert assessment of the educational content and teaching methods in use in order to see whether they are in line with present-day tasks of the energy sector and competences in demand. The analysis served as a basis for the Global Energy Business master's degree project that was implemented at Ural Federal University. The results of the research could be useful to university for bringing educational process arrangements up to date, or to energy companies for personnel development purposes.

Key words: sustainable energy, global energy education, energy business, educational program, assessment of competitiveness, university, teaching methods.
\end{abstract}

\section{INTRODUCTION}

Changes that are taking place in the global energy sector at the moment are characterized by the following trends.

Hyperconnectivity of the energy markets at the regional, national and international levels. The problems coming to the forefront are associated with finding rational solutions for the construction of major electricity and pipeline systems that spread over several countries; changes to the traditional structure of energy markets (for example, the energy commodities market is gradually converting into a market of energy services and innovative technologies); lower risks and reduced uncertainty about demand for energy carriers, prices and investment resources (Canton [1], Fredette et al. [2]).

Energy systems are growing increasingly intelligent and integrated with other infrastructure industries. Some experts observe that the energy sector is turning into a "system-of-systems" the sustainable development of which is based on the application of energy information systems, the development of "smart" energy infrastructure (Smart Grid) and multi-agent management (Agusdinata and Delaurentis [3], Mittai et al. [4], Bushuev et al. [5]).

Technologies that are used in energy generation and related processes are getting increasingly complex. E.g., new techniques are emerging for electricity accumulation and storage, long-range wireless power transfer, remote monitoring and service of energy equipment (Gudmestad and Traa [6], Boothroyd [7]). 
A transition of environmentally friendly and energy efficient production, tougher climate change regulations and an exponential growth in "clean" ("green") energy consumption, the rapid expansion of renewable energy (Genon et al. [8], Panepinto et al. [9]).

These profound and rapid changes emphasize the urgency of the problem of training professionals for work under the new conditions. More specifically, some studies indicate growing demand for specialists who have competence in engineering and economics and engineering and management, who have an equally good understanding of the nuances of new energy technologies and their impact on business results and business models of energy companies (Trachuk [10], Gielen [11], Santandreu-Mascarell et al. [12], Report [13], Chryssolouris et al. [14]). Other papers note that the global energy sector is short of workers who are familiar with the intricacies of market mechanisms in the energy sector and the relationship between technology, geopolitics, international law, and cybersecurity. In this regard, it might be interesting to analyze the market of global energy education and the content of educational products offered by leading universities, and to identify criteria that determine the competitive edge of these products in the context of the development of a new energy paradigm (Report [15], Hardcastle [16], Report [17]).

\section{ENERGY GLOBALIZATION PROBLEMS AND REQUIREMENTS FOR GLOBAL ENERGY EDUCATION}

Global energy business develops on the basis of a network of cross-national energy markets that include energy commodity markets, markets of energy innovations (both technological and organizational), energy equipment markets, engineering and energy service markets. Among those involved in the global energy market today are:

- multinational energy companies and innovation venture companies;

- intergovernmental (supranational) regulatory bodies and market regulators;

- national energy systems, either standalone or globally incorporated.

One has to bear it in mind that the development of global energy business and the global energy market is inextricably linked to numerous barriers that hamper the process. In the context of global energy business, the key problem has to do with the difficulty of creating a single platform for innovation development through the creation of a global zone for free trade in energy innovations ranging from equipment to information technologies.

The process also calls for developing unified technical standards and international regulations for global energy business and the global energy market on the basis solutions that are accepted by the energy community. The regulations should contain the following value guidelines:

1. Total openness of scientific and technological information;

2. International innovation exchange;

3. Free and non-discriminatory access of energy companies based in any country to all segments of global energy markets;

4. Cooperation among several countries for jointly designing innovative products and minimizing associated innovation risks.

Another issue of global energy market development is economic and political competition between countries. For example, power generating countries and companies leading the way in energy technology innovation seek to preserve their competitive advantages. This results 
in barriers to the spread of innovations and free access to innovative products in other countries.

It is natural to study the development of the global energy market in terms of its inextricable relationship with global energy education that forms knowledge and competencies for overcoming barriers on the way to energy market globalization and sustainable development of the energy sector. In a certain sense, global energy education is becoming a full-fledged segment of the global energy market and should be synchronized with the development of other segments.

The authors define global energy education as a multi-format process of knowledge transfer to the widest possible audience - from heads of household and students to political figures and energy professionals in the field of energy efficiency, energy conservation, sustainable development of energy markets amid globalization. Multiple formats mean that a variety of instructional methods and formats are used and that the learning process is closely integrated with research and best industrial practices. This definition of global energy education makes it possible to split it into three tiers;

- basic energy education aimed at raising awareness of a wider audience (Singh and Mulholland [18]);

- programs tailored to politicians and persons involved in making decisions about the development of the energy sector at the government and regional levels;

- advanced energy education for professionals, i.e., a new generation of energy managers. This constitutes the subject of this paper.

The main features of global energy education are (Gitelman [19], Ciobanescu Husanu and Chion [20], Gitelman and Isaev [21]):

- $\quad$ adherence to the concept of sustainable energy development that takes into account national interests, regional features and links with industrial production within the emerging industrial order;

- a comprehensive and inter-disciplinary approach to teaching that combines engineering and managerial issues;

- emphasis on a holistic vision of the entire system of the fuel and energy sector from extraction of primary energy sources to consumption of end energy carriers;

- involvement of universities, industrial and consulting companies that have previously participated in consortia in the implementation of educational products (Ilina and Putilov [22]);

- implementation of a special international project for the training of future leaders who will be capable of designing national energy programs based on the global energy development strategy (e.g., a university energy training course).

Global energy education is built on a foundation of methodological issues of national energy policies and strategies of energy corporations that are based on long-term trends in energy economics.

Changes that occur in contemporary global education are always so rapid and radical that the existing educational programs are too inert to meet new interdisciplinary requirements. 


\section{A METHODOLOGICAL APPROACH TO ASSESSING THE COMPETITIVENESS OF EDUCATIONAL PROGRAMS}

To study the present state of global energy education the authors analyzed the competitiveness of existing educational programs that are offered by leading universities of the world. Within the context of the study, competitiveness is defined as a combination of attributes that define the ability of a program to address present-day challenges confronting the global energy sector. For this purpose, a method of assessing the competitiveness of educational programs was developed. The logic behind it is shown in Fig. 1.

The approach essentially consists of calculating the average "benchmark" values of the following measures:

- language of instruction;

- annual tuition fee;

- duration of the program;

- study format.

- $\quad$ indicator of network cooperation (partnership), calculated by formula (1):

$$
\mathrm{NC}=\mathrm{U}_{\mathrm{p}}+\mathrm{C}_{\mathrm{p}}
$$

where $\mathrm{NC}$ is the network cooperation indicator; Up is the number of partner universities participating in the program; $\mathrm{Cp}$ is the number of partner companies participating in the programme;

- interdisciplinarity indicator calculated by formula (2):

$$
\mathrm{IDI}=\frac{\mathrm{Ms}}{\mathrm{M}},
$$

where IDI is the interdisciplinarity indicator; Ms is the number of modules (course) that supplement the core content of the program; $M$ is the total number of modules (courses).

Interdisciplinary courses (modules) are the ones that form knowledge to ensure a holistic vision of relationships, processes and algorithms in different fields of science and academic disciplines that are needed for solving practice-related tasks (Genon et al. [8], Panepinto et al. [9]).

IDI $=\frac{M s}{M}$ for example, in order to train energy managers, management and economic courses might be complemented with basic courses in engineering and technology and courses that cover geopolitics or energy law as modern trends. The latter will be considered supplementary to the core of the program (Gitelman and Isaev[23]).

- indicator of structural (modular) flexibility, calculated by formula (3):

$$
M F=\frac{M_{e}}{M}
$$

where MF is the indicator of modular flexibility; $\mathrm{M}_{\mathrm{e}}$ is the number of elective modules (courses);

- indicator of territorial flexibility, calculated by formula (4):

$$
\mathrm{TF}=\mathrm{DU}_{\mathrm{p}}+\mathrm{FU}_{\mathrm{p}}
$$




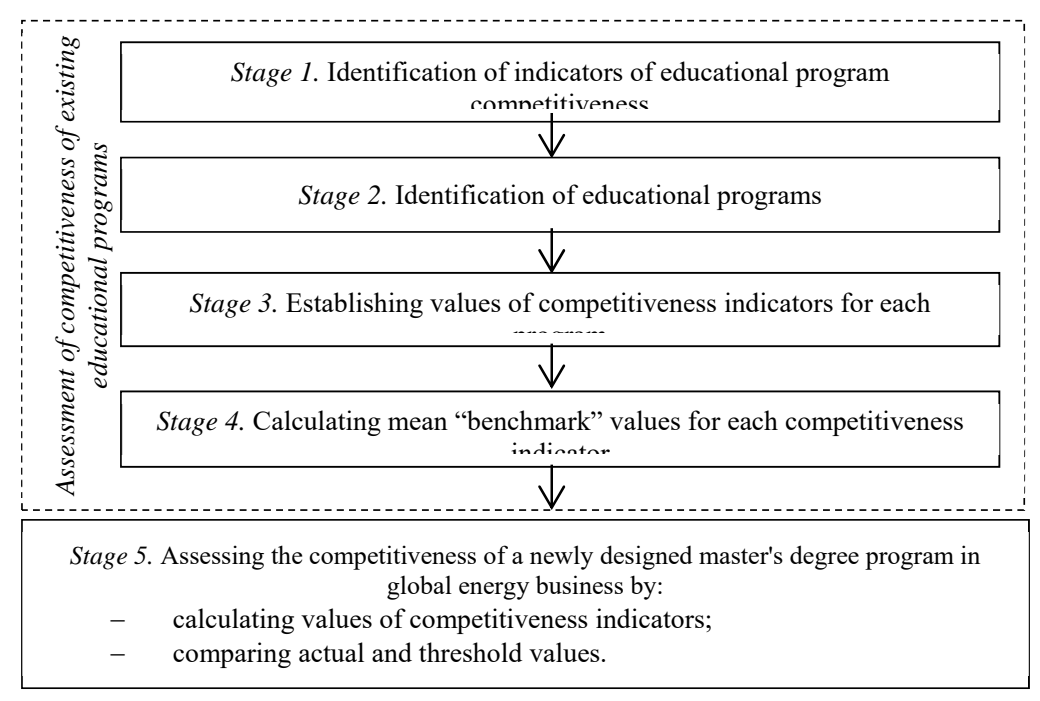

Figure 1: Methodological approach to assessment of educational program competitiveness.

where TF is the indicator of territorial flexibility; $\mathrm{DU}_{\mathrm{p}}$ is the number of domestic partner universities provide not only instructors, but also facilities (laboratories, research centers) and funding for learning; $\mathrm{FU}_{\mathrm{p}}$ is a similar indicator applied to foreign partner universities.

The designed mechanism makes it possible to compare obtained "benchmark" values with real-life indicator values of a program being developed. One of the advantages of the proposed method is not only the simplicity of calculations and the use of open-source data for evaluation, but also its high adaptability to the specific nature of the global energy sector and present-day educational standards.

\section{VALIDATION OF THE METHODOLOGICAL APPROACH ON THE BASIS OF MASTER'S DEGREE PROGRAMS IN GLOBAL ENERGY EDUCATION}

Master's degree programs that are found in the Financial Times' ranking of masters in management courses served as the basis for validating the methodological approach (Rating [24]).

The sampling included over 100 programs. The final list contained 14 master's programs in energy, only six of them being implemented as directly linked to global energy business.

The preliminary assessment results are shown in Table 1; mean "benchmark" values are in Table 2. Figs 2 and 3 depict comparative analysis of the programs.

Content analysis shows that among the six programs in global energy business that made it into the FT rating four are based in Europe (three in Great Britain and one in Scotland) and two are based in North America (USA and Canada). The care of the core curriculum in the programs ranges from $20 \%$ to $1,000 \%$ (Fig. 2).

Management courses account for $55 \%$ of the core curriculum. Law courses take up an average of 5\%, and the rest is shared by engineering and economic disciplines (Fig. 3).

The study of the structure of educational programs showed that the content of the curriculum corresponds to the challenges faced by the global energy sector (Fig. 4). For example, European universities implemented global energy programs in line with the SET 
PLAN roadmap that covers the key aspects of global energy market development (Report [25], Köhler et al. [26], Kahloun and Ghannouchi [27]).

Table 1: Educational programs in global energy.

\begin{tabular}{|c|c|c|c|c|}
\hline $\begin{array}{l}\text { University/ } \\
\text { Program }\end{array}$ & $\begin{array}{l}\text { Network } \\
\text { cooperation }\end{array}$ & $\begin{array}{l}\text { Inter- } \\
\text { disciplinarity }\end{array}$ & $\begin{array}{l}\text { Structural } \\
\text { flexibility }\end{array}$ & $\begin{array}{l}\text { Territorial } \\
\text { flexibility }\end{array}$ \\
\hline $\begin{array}{l}\text { Technical University Of Denmark/MBA “Wind } \\
\text { Energy" }\end{array}$ & 3 & $10 \%$ & $59 \%$ & 2 \\
\hline University of Warwick/MBA“Global Energy” & 0 & $7 \%$ & $40 \%$ & 0 \\
\hline $\begin{array}{l}\text { WU Executive Academy Vienna/MBA "Energy } \\
\text { Management" }\end{array}$ & 0 & $25 \%$ & $50 \%$ & 2 \\
\hline $\begin{array}{l}\text { London School of Business and Finance/"Global } \\
\text { MBA" }\end{array}$ & 0 & $17 \%$ & $38 \%$ & 0 \\
\hline $\begin{array}{l}\text { Middlesex University London / MBA “Global } \\
\text { Energy Management" }\end{array}$ & 0 & $5 \%$ & $33 \%$ & 0 \\
\hline $\begin{array}{l}\text { University of Strathclyde Business School / MBA } \\
\text { "Global Energy Management" }\end{array}$ & 4 & $20 \%$ & $30 \%$ & 4 \\
\hline $\begin{array}{l}\text { Grenoble Graduate School of Business / MBA } \\
\text { "Advanced Master's In Energy Marketing And } \\
\text { Management" }\end{array}$ & 0 & $20 \%$ & $10 \%$ & 1 \\
\hline $\begin{array}{l}\text { ESCP Europe Business School/MBA “Energy } \\
\text { management": Executive Masters }\end{array}$ & 0 & $21 \%$ & $20 \%$ & 3 \\
\hline $\begin{array}{l}\text { ESCP Europe Business School/MBA “Energy } \\
\text { management": MSc }\end{array}$ & 0 & $20 \%$ & $15 \%$ & 1 \\
\hline $\begin{array}{l}\text { Business School University of Colorado/MBA } \\
\text { "Global Energy Management" }\end{array}$ & 0 & $12,5 \%$ & $50 \%$ & 0 \\
\hline University of Calgary/MBA "Global Energy" & 5 & $4 \%$ & $0 \%$ & 5 \\
\hline $\begin{array}{l}\text { Tulane University: Freeman School of } \\
\text { Business/ "Master of Management in Energy" }\end{array}$ & 0 & $11 \%$ & $20 \%$ & 1 \\
\hline $\begin{array}{l}\text { University Technology Petronas/MBA “Energy } \\
\text { Management" }\end{array}$ & 0 & $12,5 \%$ & $10 \%$ & 0 \\
\hline $\begin{array}{l}\text { Kyoto University/“International Energy Science } \\
\text { Course” }\end{array}$ & 0 & $36 \%$ & $10 \%$ & 2 \\
\hline $\begin{array}{l}\text { "Global Renewable Energy Education and } \\
\text { Training (GREET)" }\end{array}$ & Depends on & $25 \%$ & $0 \%$ & Depends on \\
\hline $\begin{array}{l}\text { "UNESCO/ISEDC Cosponsored Fellowships } \\
\text { Program" }\end{array}$ & 1 & $30 \%$ & $0 \%$ & 0 \\
\hline $\begin{array}{l}\text { REC Renewable Types of Energy and } \\
\text { Installations/ Master's programs "Non } \\
\text { conventional sources of energy and renewable", } \\
\text { "Design, building and management of renewable } \\
\text { energy installations" }\end{array}$ & 1 & $15 \%$ & $10 \%$ & 0 \\
\hline
\end{tabular}

Table 2: General assessment of master's programs.

\begin{tabular}{|l|c|}
\hline \multicolumn{1}{|c|}{ Indicator } & Mean values \\
\hline Language of instruction & English \\
\hline Annual tuition fee, $\$$ & $1760000(29300)$ \\
\hline Duration. years & $1.5-2$ \\
\hline Study format & Full time and online \\
\hline Number of network partners & 0.7 \\
\hline Interdisciplinarity level, \% & 17.1 \\
\hline Structural flexibility, \% & 24.3 \\
\hline Territorial flexibility & 1.1 \\
\hline
\end{tabular}




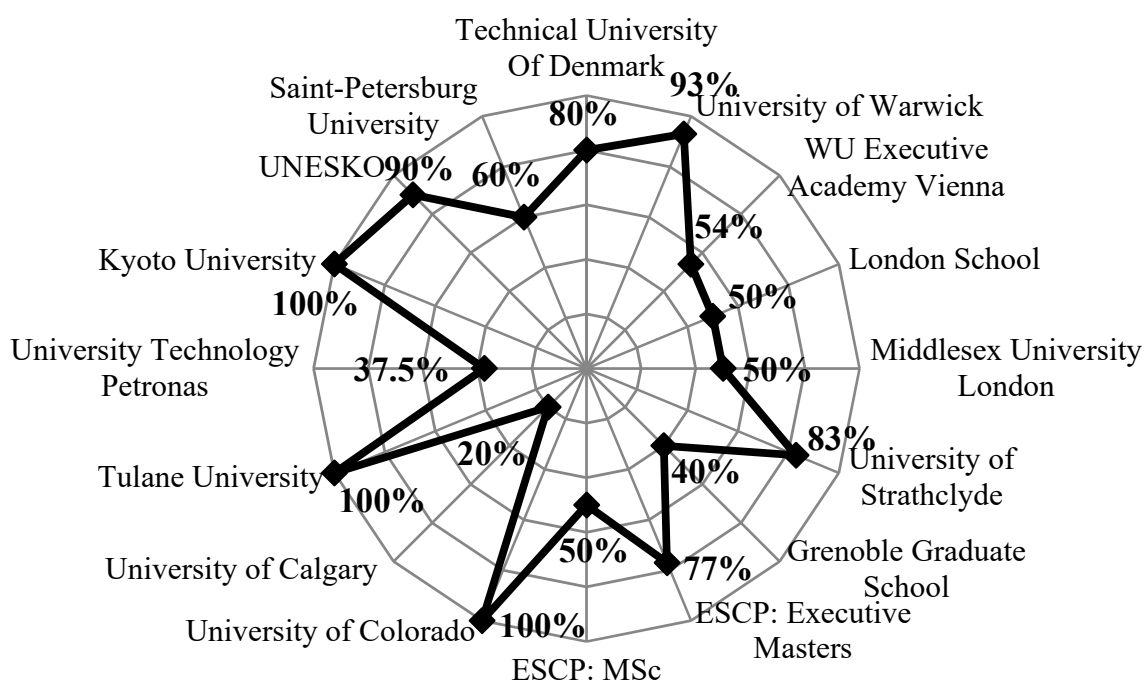

Figure 2: Share of core job-related disciplines in master's programs.

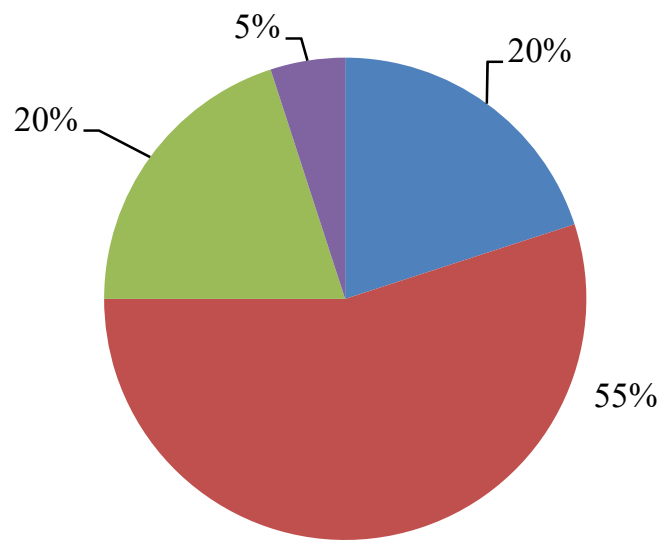

Engineering courses

- Management courses

- Economic courses

- Law

Figure 3: Structure of core disciplines in master's programs. 


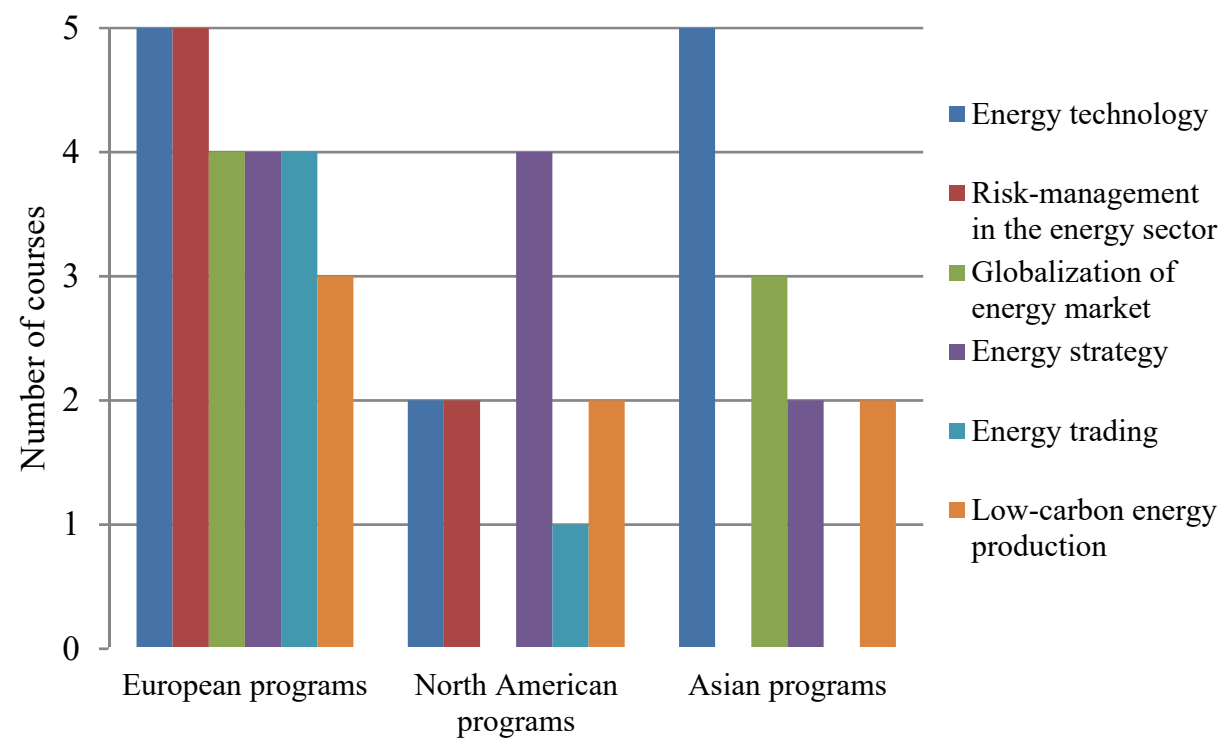

Figure 4: Popular courses within master's programs.

5 GLOBAL ENERGY BUSINESS PROGRAM AT URAL FEDERAL UNIVERSITY

The research and educational centre for engineering and economic interdisciplinary studies and educational programs of Ural Federal University (REC Inzhek) has created and implements a master's programe called "Global Energy Business". The objective of the program is to train management professionals with a potential to advance their career to the level of top management and leading analysts with a broad vision and unconventional approaches capable of operation on global and national energy markets.

Fig. 5 shows a general structure of the program components. The sufficient number of engineering courses included in the program is in line with contemporary trends in global energy education. Among the engineering courses comprised by the program are disciplines that study the development of cutting-edge energy technology, energy efficiency and energy conservation, including renewables, environmental issues faced by energy companies, energy maintenance services, energy service etc. (Lanshina and Barinova [28], Berengarten et al. [29], Margun et al. [30]).

An assessment of the educational program conducted using the proposed methodology yielded results that are summarized in Table 3. As prescribed by the methodology, mean values were accepted as benchmarks for assessing the competitiveness of the newly designed program in the field of global energy. The calculations indicate that the new program outperforms the benchmarks for all indicators, which is a proof of its competitive advantage. 


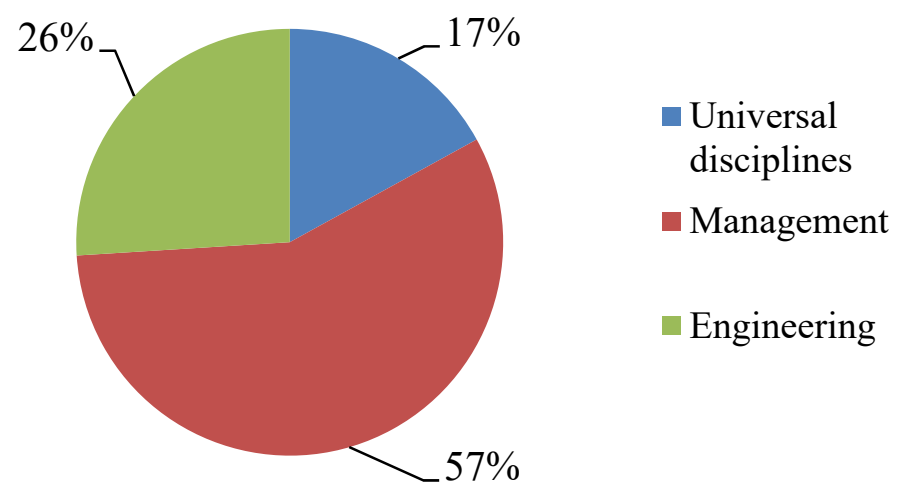

Figure 5: Structure of the curriculum of Global Energy Business program.

Table 3: Assessment of the competitive of educational program "Global Energy Business".

\begin{tabular}{|l|c|c|}
\hline \multicolumn{1}{|c|}{ Indicator } & $\begin{array}{c}\text { Value for Global } \\
\text { Energy Business } \\
\text { program }\end{array}$ & Relation to mean value \\
\hline Language of instruction & English & $=$ \\
\hline Annual tuition fee, $\$$ & $3,500-4,000$ & $\approx$ \\
\hline Duration, years & 2 & $>>$ \\
\hline Study format & Full time & $=$ \\
\hline Number of partners & 4 & $>>$ \\
\hline Interdisciplinary level & 17,1 & $\approx$ \\
\hline Structural flexibility, $\%$ & $85,7(77,1)$ & \\
\hline Territorial flexibility & 1 & \\
\hline
\end{tabular}

\section{CONCLUSION}

The analysis established that despite a general trend only a handful of universities and educational establishments across the globe added global energy education to their priority agenda. Nevertheless, the number of universities that realize the importance of energy education and start to implement relevant projects grows year-on-year (Krivova et al. [31], Turner [32]).

The authors' investigations prove the expanding role of the combination of engineering and economic and engineering and managerial competencies against the backdrop of technological advances in the energy sector. The highly dynamic and turbulent environment, uncertainty and risks highlight the importance of adopting the principles of "forwardlooking" education at universities. Forward-looking education becomes especially critical for the highly inert and capital-intensive energy sector as, among other things, it addresses the issues of communication with pro-active consumers (Rukavishnikova et al. [33], Ocetkiewicz [34]). 
Forward-looking education focuses on the study of methods and practices of detecting dangerous fluctuations in the external environment and countering global threats. Trendsetting foreign innovations are analyzed to see whether they can be applied in individual national economies and whether they need to be fine-tuned (localized). Good methodological products that have been successfully tested can be considered an internationally marketable scientific product or an item for exchange with partners abroad. It also makes sense to forge ties between major energy countries in different countries in order to elaborate common approaches to building effective management systems that are designed to deal with new challenges, and to implement educational products in cooperation with consulting companies and centers of expertise and analysis.

\section{ACKNOWLEDGEMENT}

The work was supported by Act 211 of the Government of the Russian Federation, contract № 02.A03.21.0006.

\section{REFERENCES}

[1] Canton, J., Future Smart: Managing the Game-Changing Trends that Will Transform Your World. Boston: Da Capo Press, p. 402, 2015.

[2] Fredette, J., Marom, R., Steinert, K. \& Witters L., The Promise and Peril of Hyperconnectivity for Organizations and Societies. The Global Information Technology Report, Living in a Hyperconnected World, ed. Dutta, S. \& Bilbao-Osorio, B. Geneva: SRO-Kunding. p. 415, 2012.

[3] Agusdinata, D.B. \& DeLaurentis, D., Specification of system-of-systems for policymaking in the energy sector. The Integrated Assessment Journal, 8(2), pp. 1-24, 2008.

[4] Mittai, S., Ruth, M., Pratt, A., Lunacek, M., Krishnamurthy, D. \& Jones, W., A systemof-systems approach for integrated energy systems modeling and simulation. Proceedings of the Conference on Summer Computer Simulation, Chicago, Illinois 26-29 July, pp. 1-10, 2015.

[5] Bushuev, V.V., Kamenev, A.M. \& Kobets, B.B., Energetika kak infrastrukturnaia «sistema sistem» [Energy business as the system-of-systems infrastructure]. Energeticheskaia politika, Energy Policy, No 5, pp. 3-15, 2012.

[6] Gudmestad, O.T. \& Traa, K., Sustainable Use and Production of Energy In The 21st Century. International Journal of Energy Production and Management, 1(1), 2016, pp. 1-15.

[7] Boothroyd, R.G., A Suggested Roadmap for World-wide Energy Resource Planning and Management. International Journal of Energy Production and Management, 1(1), pp. 72-86, 2016.

[8] Genon, G., Panepinto, D. \& Viggiano, F., Sustainability in Energy Production. International Journal of Energy Production and Management, 1(1), pp. 16-32, 2016.

[9] Panepinto, D., Zanetti, M.C., Gitelman, L., Kozhevnikov, M., Magaril, E. \& Magaril, R., Energy from Biomass for Sustainable Cities. IOP Conf. Series: Earth and Environmental Science, 72, http://iopscience.iop.org/article/10.1088/17551315/72/1/012021, 2017.

[10] Trachuk, A.V., Biznes-modeli dlia gipersviazannogo mira [Business models for hyperconnected world]. Upravlencheskie nauki v sovremennoi Rossii [Management sciences in modern Russia], 1(1), pp. 20-26.

[11] Gielen, G., Final overview of the expected competencies of future nano-electronics engineers. Work Package 1 - Study of future training needs in micro/nano-electronics, 
2011. http://cordis.europa.eu/docs/projects/cnect/1/257051/080/deliverables/001EurodotsD12.pdf

[12] Santandreu-Mascarell, C., Canós-Darós, L. \& Pons-Morera, C., Competencies and skills for future Industrial Engineers defined in Spanish degrees. Journal of Industrial Engineering and Management, 4(1), pp. 13-30, https://riunet.upv.es/bitstream/handle/ 10251/28361/JIEM-Cristina-Lourdes-Carlos.pdf?sequence=1, 2011.

[13] Engineering the future - a vision for the future of UK engineering, https://www.engc.org.uk/EngCDocuments/Internet/Website/Engineering\%20the $\% 20$ future\%20-\%20Manifesto.pdf

[14] Chryssolouris, G., Mavrikios, D. \& Mourtzis, D., Manufacturing Systems: Skills \& Competencies for the Future. Procedia CIRP, 7, pp. 17-24, 2013.

[15] Study of occupational and skill needs in renewable energy: final report/International Labour Office, ILO Skills and Employability Department (EMP/SKILLS) - Geneva: ILO, 2011.

[16] Hardcastle, A., Smart Grid Skills for the Energy Workforce, 2013, http://cleanenergyexcellence.org/wp-content/uploads/2014/08/Smart-Grid-Skillsreport-10-1-13.pdf

[17] Skills in Energy: Bringing the Gap, https://www.siemens.co.uk/pool/insights/skills-inenergy-bridging-the-gap.pdf

[18] Singh, J. \& Mulholland, C., DSM in Thailand: A Case Study, 2000, http://documents.worldbank.org/curated/en/586411468764049344/pdf/318680dsm1t hailand100.pdf

[19] Gitelman, L.D., Management Education for A Sustainable Electric Power Industry in the 21st Century. WIT Transactions on Ecology and the Environment, 190, pp. 1195$1203,2014$.

[20] Ciobanescu Husanu, I.N. \& Chiou, R., Embedding Global Energy Education into Engineering Technology Curricula: The Development and Implementation of Green Energy and Sustainability ET Minor. American Society for Engineering Education. 2017.

[21] Gitelman, L.D. \& Isaev, A.P., Ambitsioznye menedzhery: Derzost' i intellekt [Ambitious managers: Audacity and intellect]. Moscow, Delo, pp. 200-210, 2004.

[22] Ilina, N.A. \& Putilov, A.V., Analiz stanovleniia, tekushchee sostoianie i perspektivy razvitiia osnovnykh uchastnikov mirovogo innovatsionnogo atomnogo rynka [Analysis of the rise, current state and development prospects of the key participants in the global innovative nuclear power market]. Innovatsii [Innovations], No. 9, pp. 39-44, 2012.

[23] Gitelman, L.D. \& Isaev, A.P., Menedzhery novogo pokoleniia. Peredovoe upravlencheskoe obrazovanie [New generation managers. Cutting-edge management education]. Moscow, Ekonomika, pp. 100-104, 2014.

[24] Rating Financial Times «Masters in Management 2016», 2017. http://rankings.ft.com/businessschoolrankings/masters-in-management-2016.

Accessed on: 22 Apr. 2017.

[25] European Research Advisory Board Report on European Technology Platforms: Report, 2004. Accessed on: 20 Apr. 2017.

[26] Köhler, A.R., Bakker, C. \& Peck, D., Critical materials: a reason for sustainable education of industrial designers and engineers. European Journal of Engineering Education, 38(4), pp. 441-451, 2013. 
[27] Kahloun, F., Ghannouchi, S.A., Evaluation of the criteria and indicators that determine quality in higher education: A questionnaire proposal. Smart Innovation, Systems and Technologies, 76, pp. 565-574. 2018.

[28] Lanshina, T.A. \& Barinova, V.A., Global'noe upravlenie v sfere vozobnovliaemoi energetiki: mezhdunarodnye tendentsii i Rossiia (The global governance of renewable energy: International Trends and Russia). Vestnik mezhdunarodnykh organizatsii, International Organisations Research Journal, 12 (1), pp. 110-126. 2017.

[29] Berengarten, B., Sevastianov, A. \& Tiukhov, I. (2013) Opyt podgotovki inzhenernykh kadrov po ispol'zovaniia vozobnovliaemykh istochnikov energii na kafedre IUNESKO «Tekhnika ekologicheski chistykh proizvodstv» [Exercise in training engineering personnel for renewable energy use at the UNESCO-sponsored department "Environmentally friendly production"]. Energeticheskoe obrazovanie i podgotovka spetsialistov dlia vozobnovliaemoi energetiki [Energy education and professional training for renewable energy], No. 16.

[30] Margun, A., Kremlev, A., Bazylev, D. \& Zimenko, E., Impact of international accreditation for education in the Russian Federation. Smart Innovation, Systems and Technologies, 75, pp. 450-458, 2018.

[31] Krivova, L., Imas, O., Moldovanova, E., Mitchell, P.J., Sulaymanova, V. \& Zolnikov, K., Towards smart education and lifelong learning in Russia. Smart Innovation, Systems and Technologies, 70, pp. 357-383, 2018.

[32] Turner, W., Energy and politics. Strategic Planning for Energy and the Environment, 33(2), pp. 5-6, 2013.

[33] Rukavishnikova, I., Rumyantseva, A. \& Plastinina, I., Environmental Component in Economic Efficiency of Renewable Energy Projects. International Journal of Sustainable Development and Planning, 5, 2017.

[34] Ocetkiewicz, I., Tomaszewska, B. \& Mróz, A., Renewable energy in education for sustainable development. The Polish experience. Renewable and Sustainable Energy Reviews, 80, pp. 92-97, 2017. 